The Journal of SPORT, 2013, 2(1), 1-20

(C) Kent State University

\title{
Time Allocation of Sales Activities in Professional Sport Organizations
}

David Pierce

Ball State University

\section{Jeffrey Petersen}

Baylor University

\section{Donghun Lee}

Ball State University

\begin{abstract}
The sale of tickets, premium seating, and sponsorship is fundamental to the financial viability of professional sport organizations. With ticket sales as the most important source of local revenue for most sport organizations and the sale of premium suites and sponsorships unshared amongst other franchises (Smith \& Roy, 2011; Howard \& Crompton, 2004), recruiting, training, and retaining high quality salespeople is an important managerial function of professional sport franchises (Irwin, Sutton, \& McCarthy, 2008; Pierce, Petersen, Clavio, \& Meadows, in press). Although researchers have examined sales activities in many industries, little research exists on how salespeople utilize their time in the sport industry. Sport salespeople have a variety of responsibilities, from cold calling to working on game day (Pierce et al., in press). However, sales activities might differ based on salesperson characteristics such as gender and experience, or by organization based on level of competition or what is being sold. The purpose of this study was to determine how much time sport sales personnel spend on a variety of sales tasks, examine differences between types of sales employees, and determine if time spent on sales tasks predicts job performance or satisfaction.
\end{abstract}




\section{Literature Review}

Frederick Taylor"s pioneering essay of 1911, The Principles of Scientific Management, formed the foundation of time and motion study as a gateway to the improvement of worker practices (Bell, 2011). Three key concepts encapsulated the approach of scientific management including: the study and analysis of work in order to discover the best way and proper time to perform a job, a scientific process for selecting and training the workforce, and disciplined work performance by labor coupled with analysis and control by management (Covell et al., 2007). The application of the tenants of Taylor"s scientific management to the area of sales was quickly established by Charles Hoyt who published his text Scientific Sales Management in 1912 (LaLonde \& Morrison, 1967). Despite the early and expanding work related to the application of scientific management concepts to the sales process, there has been no documented study of the time allocation of sales tasks and activities specific to the sport industry setting.

Salespeople have a number of job duties and responsibilities, and several prior studies have sought to identify and classify these tasks. Moncrief (1986) created the first comprehensive inventory of sales activities that was applied in the setting of selling industrial products. Additional research by Moncrief, Marshall, and Lassk (2006) updated this inventory and conducted a factor analysis that identified twelve dimensions of selling, including relationship selling, promotional activities and sales service, entertaining, prospecting, computer, travel, training/recruiting, delivery, product support, educational activities, office, and channel support. Beck and Knutson (2006) used a similar methodology, but applied it to the hotel industry, and Authors (in review) performed an exploratory and confirmatory factor analysis of sport sales activities.

Sales activities within the sport industry have been examined primarily through content analysis of sport sales position announcements. Pierce et al. (2012) performed a content analysis of 335 ticket sales and service position announcements over a sixmonth time frame. Six of the eighteen job responsibilities, which included cold calling, customer service, prospecting, database 
management, game day duties, and presenting, were identified in at least half of the job announcements.

Bae and Miller (2011) examined 209 sport marketing job announcements over a six-month time frame. While the sampling frame was broader than in the Pierce et al. (in press) study, the top job duties in sport marketing positions were sales related. The following three duties were identified in over forty percent of the announcements: 1) overseeing sales and services for individual, group, premium seating, club seats, and suites; 2) developing new sales strategies and packages for customers; and 3) meeting established sales objectives via cold calling and in-person sales.

How salespeople allocate their time has been examined in the business literature with a focus on sales performance. Kerber and Campbell (1987) found little association between the proportion of time devoted to various work activities and sales performance. Similarly, Weeks and Kahle (1990) found no relationship between time spent calling on existing accounts or potential accounts and sales performance. Beck (2006) and Beck and Knutson (2006) examined the sales time allocation for hotel sales managers, who spent the greatest amount of time in face-to-face selling, followed by prospecting, account servicing, preparing requests for proposals, and completing paperwork. Beck (2006) examined differences between full and limited service hotel sales managers. Limited service hotel sales managers reported spending more time in face-to-face selling and training others, while full service hotel sales managers reported spending more time preparing requests for proposals.

Similar to Beck (2006), this present study examined group differences, but also included measures of performance. Specifically, this study examined differences in sales time allocations based on gender (male/female), title (director/non-director), organizational level (minor league/major league), and type of sales (season tickets/groups and businesses). The relationship between market size and years of sales experience is also explored. The rationale for these comparisons is presented next.

First, gender differences within sales processes have been examined in prior research. One important trend in sales is the 
movement away from the transaction-based sales model to relationship-focused sales (Weitz, Castleberry, \& Tanner, 2009). Studies have found that females are more interested and better at developing and maintaining sales relationships than males (Beetles \& Crane, 2005; Groysberg, 2008; Sigauw \& Honeycutt, 1995). Males and females approach the sales relationship from different perspectives (McQuiston \& Morris, 2009). Women are more relational and attempt to build relationships prior to achieving goals, while men tend to focus on goal achievement prior to relationship building (Heaston, 2005). Males and females also differ on verbal and non-verbal communication (McQuiston \& Morris). Despite the noted differences in sales approaches and styles, no prior research has examined time allocation of sales tasks by gender.

Second, differences have previously been found between directors and non-director sales position in sport organizations. In their content analysis of sport ticket sales position announcements, Pierce et al. (2012) found that directors were nearly seven times more likely to perform financial management activities and seven times more likely to supervise other salespeople. Third, differences in sport sales roles based upon leagues levels have also been studied in the past. Petersen, Pierce, and Judge (2011) examined difference between minor league and major league organizations in sales position announcements using content analysis methodology. With regard to job responsibilities, major league positions were more likely to identify game day duties, renewals, facility tours, and upselling. In terms of transferrable skills, major league organizations were more likely to identify long hours, organizational skills, interpersonal relation, and bilingualism than minor league franchises. This study offers a unique contribution compared to the previous studies by virtue of the survey methodology employed.

Fourth, sport sales can be categorized by the type of product sold or the target market of the sales effort. Professional sports is sold to four distinct stakeholder groups, including fans, television and other media, communities, and corporations (Mason, 1999). Individual fans purchase season and individual tickets; pay for concessions, parking, and licensed goods; and attend games to be 
entertained by the unknown outcome of the game or other product extensions that are entertaining (Mason). Organizations and businesses purchase group seats, premium seats to entertain clients and employees, and sponsorship to associate with the sport organization and achieve marketing objectives. The task and activities of a salesperson could be different based on whether they are selling to individual fans or corporations.

Fifth, the relationship between market size and sales activities has not been examined previously. However, it is possible that the activities of sport sales personnel could be different if they were located in a small town compared to a large urban area. For example, Pierce and Petersen (2011) examined sponsorship sales in Indiana high schools and found that non-rural schools were nearly three times more likely than rural schools to activate sponsorship through on-site promotions.

Finally, the level of experience in sales or length of tenure within the sport organization can also play a role in the nature of one"s job responsibilities. There are four career stages in sales as outlined by Irwin, Sutton, and McCarthy (2008) based on the work of Cron (1984). In the exploration phase, sales professionals are searching for support, challenges, a career path, and the situation that best fits their needs. In the establishment phase, young professionals put in long hours of hard work to establish their reputation and credentials. If successful, sports ticket sales representatives often have options to move into sponsorship sales, premium sales, or management. In the maintenance stage, salespeople rely on their experience and network of contacts to achieve high levels of sales without working as hard as those in the establishment stage. Finally, in the disengagement phase, veteran salespeople tend to not be as competitive and prioritize other areas of their life ahead of their career. These individuals can become difficult to motivate and incentivize. Sport sales related research has identified differences between entry-level and non-entry-level positions (Pierce et al., 2012). Entry-level positions were four times more likely to require cold calling and receipt of inbound calls, while non-entry-level 
positions were nearly five times more likely to seek employees who would supervise other salespeople.

Because empirical examination of the nature of sport sales positions remains relatively limited, the results of this study provide additional insights into the nature of sport sales. While Pierce et al. (2012) and Bae and Miller (2011) were able to identify the percentage of job descriptions that identified required job functions, the content analysis methodology used in both studies was unable to differentiate the amount of time spent on the variety of sales tasks and job responsibilities. There are numerous implications from this research for multiple stakeholders including sport management students considering a career in sales, sport management faculty preparing curricula to prepare students for a career in the sport industry, and sport organizations who need to train productive salespeople to generate revenue.

In order to provide a structural framework for this investigation, the following research questions guided this study:

1) How many hours per week do sport sales personnel spend on various sales tasks?

2) What differences exist on how much time is spent on various sales tasks based on gender (male/female), title (director/nondirector), organizational level (minor league/major league), or type of sales (season tickets/groups and businesses)?

3) What is the relationship between market size (population) and time spent on sales activities?

4) What is the relationship between years of experience in sport sales and time spent on sales activities?

5) Does the amount of time spent on various sales activities predict sales performance, satisfaction, or persistence in sport sales?

\section{Participants}

\section{Methods}

A database of 4,677 sport salespeople at the professional level was compiled from team websites from the National Football League, Major League Baseball, National Basketball Association, Women"s National Basketball Association, Major League Soccer, 
the National Hockey League, East Coast Hockey League, American Hockey League, Minor League Baseball (MiLB) International League, MiLB Midwest League, and MiLB Southern League.

The majority of respondents were male $(73.8 \%)$, and females accounted for $26.2 \%$ of the sample. Account Executives accounted for $67.7 \%$ of the respondents, while $13.1 \%$ described themselves as a Director, $14.7 \%$ were Managers, and 4.5\% were Vice Presidents. The sports of baseball (36.1\%), hockey (26.6\%), and basketball $(23.6 \%)$ were the sports most represented in the survey, followed by football (8.4\%), and soccer (5.2\%). A large majority worked at the Major League level (71.1\%) while 28.9\% worked at the Minor League level. Over half of the respondents were responsible for group ticket sales (58.1\%) and season ticket sales (57.0\%), while $33.1 \%$ were responsible for premium sales, $23.5 \%$ described themselves as responsible for inside sales, and $21.9 \%$ handled Sponsorship. On average, the respondents had five years of experience working in sport sales $(M=4.99, S D=4.31)$.

\section{Survey}

A 78-item questionnaire, divided into four sections, was developed through an extensive literature review (Beck \& Knutson, 2006; Moncrief, 1986; Moncrief, Marshall, \& Lassk, 2006; Pierce et al., in press). Initial drafts of the surveys were distributed to ten academic and industry experts in sport sales in order to establish face and content validity. Section 1 contained the following demographic questions: title (account executive, director, manager, vice president); gender; years of experience in sport sales; employer; primary job responsibility (group sales, inside sales, season ticket sales, sponsorship sales, premium sales); and percentage of annual sales goal achieve last year.

Section 2 contained 56 items using the following question stem on a 7-point Likert scale: "Please rate the relative importance of the following sales tasks toward your success as a salesperson." Section 3 contained ten items regarding how much time (hours per week) salespeople spend on the following sales activities: prospecting, sales call planning, face-to-face selling, selling over the 
phone, preparing requests for proposals, traveling to meet with clients, servicing accounts, professional development, organizational tasks, and sales force management. Section 4 contained the following four Likert-scale questions: I am satisfied with my job; I want to continue working in sport sales; I can achieve success in sport sales; and I am one of the top sales people in my office $(\alpha=$ .730). This article focuses on the results to Section 3 and 4 and uses demographic questions from section 1 to compare differences between groups. Approval was sought and obtained by the Institutional Review Board at the lead author"s institution.

\section{Procedure}

Participants were recruited to complete the questionnaire by direct mail via the United States Postal Service. Participants were given the option to complete the hard copy questionnaire inside the direct mailing, or to complete an online survey placed on the website www.sportsales.info, which was created specifically to host the online survey. Sixty-six mailings were returned to sender due to an invalid mailing address, and 4,611 surveys reached the intended destination. A total of 529 participants returned the survey (141 online, 388 paper) yielding an $11.5 \%$ response rate. A total of 457 respondents completed sections 3 and 4 of the survey instrument, which are the sections examined in this paper.

\section{Data analysis}

Non-parametric statistical procedures were utilized because the measurement variables did not meet the normality assumption. As a result, the Mann-Whitney U-test was utilized to compare group differences in gender, title (account executive vs. director), level (major league vs. minor league), and season tickets (individual season tickets vs. selling to groups and businesses) because each nominal variable was dichotomous. Because four analyses were being performed for the same variables, the Bonferroni inequality adjustment was utilized to control for Type I error, creating a new significance value at $p=.0125$ (i.e., .05/4; Hair, Black, Babin, \& 
Anderson, 2010). The data was analyzed using the SPSS Version 19.0.

\section{Results}

Table 1 identifies the overall descriptive statistics for each sales activity. Sport sales personnel reported spending 14.6 hours per week selling on the phone, accounting for $27.3 \%$ of their work week. However, the standard deviation for selling on the phone was 11.5, indicating that there was quite a bit of variability between groups, which will be examined in more detail. Assuming the ten tasks represented in the survey accounted for all of a salespersons" time, they reported working on average 53.4 hours per week, but the standard deviation was 20.22 , indicating that many sales personnel work more or less than 53 hours per week.

Table 1

Hours per Week Spent on Sales Tasks

\begin{tabular}{lrrrc}
\hline \multicolumn{1}{c}{ Task } & $M$ & $S D$ & Pct. & $N$ \\
\hline Selling on phone & 14.6 & 11.5 & $27.3 \%$ & 457 \\
Servicing & 8.6 & 8.8 & $16.1 \%$ & 457 \\
Organizational tasks & 7.3 & 6.4 & $13.7 \%$ & 457 \\
Prospecting & 5.5 & 5.8 & $10.3 \%$ & 457 \\
Sales force management & 4.1 & 8.6 & $7.7 \%$ & 457 \\
Presenting & 3.5 & 3.2 & $6.5 \%$ & 457 \\
Planning & 3.1 & 2.8 & $5.8 \%$ & 457 \\
Preparing bids & 2.4 & 3.0 & $4.5 \%$ & 457 \\
Traveling & 2.2 & 3.1 & $4.1 \%$ & 457 \\
Professional development & 2.1 & 2.3 & $3.9 \%$ & 457 \\
Total & 53.4 & 20.2 & $100 \%$ & 457 \\
\hline
\end{tabular}

Table 2 displays the $z$ value for the Mann-Whitney U tests. First, gender differences were detected on servicing $(\mathrm{U}=12766, z=$ $4.30, p=.001, r=.20)$ and organizational tasks $(\mathrm{U}=14002, z=$ $3.32, p=.001, r=.16)$. Females spent more time on servicing accounts and organizational tasks than males. 
Second, job title differences were detected on prospecting (U $=18748.5, z=2.58, p=.010, r=.12)$, selling on the phone $(\mathrm{U}=$ $12659, z=7.33, p=.001, r=.34)$, professional development $(\mathrm{U}=$ $16052, z=4.75, p=.001, r=.22)$, and sales force management $(\mathrm{U}=$ $6624.5, z=12.41, p=.001, r=.58$ ). Account executives spent more time on prospecting and selling on the phone than directors. In contrast, directors spent more time on engaging in professional development and sales force management than account executives.

Third, no differences were detected between sales personnel at the major league and minor league level. Finally, significant differences were detected between those charged with selling season tickets and those charged with selling group tickets, premium seats and sponsorships to groups and businesses. Salespeople assigned to selling to groups and businesses spent more time than those selling season tickets on prospecting $(\mathrm{U}=19027, z=4.03, p=.001, r=$ $.19)$, planning $(\mathrm{U}=20533, z=2.93, p=.003, r=.14)$, presenting (U $=18008.5, z=4.78, p=.001, \mathrm{r}=.22)$, preparing bids $(\mathrm{U}=18266.5$, $z=4.53, p=.001, r=.21)$, and traveling $(\mathrm{U}=17563, z=5.17, p=$ $.001, \mathrm{r}=.24)$. Salespeople focused on selling season tickets spent more time selling on the phone than those selling groups, premium seats, and sponsorships to a corporate audience $(\mathrm{U}=19043, z=4.0$, $p=.001, r=.19)$. 
Table 2

Mann Whitney U Test Z-values Comparing Differences between Gender, Title, and League Level and Product Sold

\begin{tabular}{lcccc}
\hline Task & Gender & Title & \multicolumn{2}{c}{ League } \\
& & & Product \\
Level & Sold \\
\hline Prospecting & 2.36 & $2.58^{*}$ & .30 & $4.03^{*}$ \\
Planning & .45 & .31 & 1.15 & $2.93^{*}$ \\
Presenting & 1.27 & 2.41 & 1.47 & $4.78^{*}$ \\
Selling on phone & .01 & $7.33^{*}$ & .99 & $4.00^{*}$ \\
Preparing bids & 2.32 & 1.91 & .87 & $4.53^{*}$ \\
Traveling & .38 & .08 & .67 & $5.17^{*}$ \\
Servicing & $4.30^{*}$ & .18 & .87 & .27 \\
Professional development & .81 & $4.76^{*}$ & .68 & .72 \\
Organizational tasks & $3.32^{*}$ & 2.39 & .43 & 1.25 \\
Sales force management & .84 & $12.41^{*}$ & 1.90 & .49 \\
\hline
\end{tabular}

Note. *Significant difference at .0125 level using Bonferroni inequality adjustment (Hair et al., 2010).

Research Question 4 sought to examine if years of experience in sport sales had an effect on the time spent on certain sales tasks. Prospecting $(r=-.10)$ and selling on the phone $(r=-.18)$ were negatively correlated with years of experience, while professional development $(\mathrm{r}=.10)$, and sales force management $(r=$ .23) were all positively correlated with years of experience in sport sales. However, only selling on the phone $(=-.046)$ and sales force management $(=.101)$ were significant predictors of one"s years of experience in sport sales, $F(10,453)=4.448, p=.001$, adjusted $\mathrm{R}^{2}=.071$.

The size of the market in which the sport organization resided was also examined, operationalized by the population of the city in which the team resided. The regression result was insignificant, but a significant positive correlation was identified between population and prospecting $(r=.10)$. 
The amount of time spent on various sales activities did not predict job satisfaction, the extent to which the sales person believed they could achieve success in sport sales, the extent to which the sales person believed they were one of the top salespeople in the office, or sales productivity as measured by the percentage of sales goals achieved in the last year. However, time spent on sales activities did predict wanting to continue working in sport sales. Professional development $\left(_{\beta}=.039\right)$ and sales force management $\left(_{\beta}=.016\right)$ were significant predictors of one"s wanting to continue working in sport sales, $F(10,448)=2.59, p=.005$, adjusted $\mathrm{R}^{2}=$ .034. Lastly, total hours per week worked was not significantly correlated to any of these variables.

\section{Discussion}

The sport sales personnel surveyed in this study spent the greatest amount of time selling on the phone, which accounted for over one-fourth of the work week. Selling on the phone is an activity fundamental to selling. Pierce et al. (2012) found cold calling was the most commonly identified sales task in sport sales position announcements. However, not all sales positions are created the same. Account executives and sales personnel focusing on sale of season tickets focus a majority of their efforts on selling over the phone, which explains the large standard deviation in hours per week spent selling on the phone. Because these positions are readily available for those seeking entry-level employment in the sport industry, sport management programs offering sales courses should include selling over the phone as an experiential learning component of any sales class to appropriately prepare students for the nature of sport sales positions (Pierce \& Petersen, 2010; Pierce, Petersen, \& Meadows, 2011).

Servicing accounts was second behind selling on the phone with 8.4 hours per week. It is important to note that "customer service" representatives were not surveyed in this study, meaning account servicing is an activity for which salespeople allocate significant time. Some organizations, including many minor league organizations, may not have personnel allocated specifically to 
customer service, but this result clearly indicates that salespeople also need to have a skill set conducive to servicing accounts. Sport organizations should ensure that training efforts focus on how to service accounts in addition to time spent training on sales technique.

Salespeople in this survey spent the third greatest amount of time on organizational tasks, which confirms the results of Pierce et al. (2012) that found organizational skills were identified in over half of all sport sales job announcements. While most jobs require organizational skills, the fact that salespeople reported spending more than seven hours per week on organizational tasks speaks to the importance of skills like time management and scheduling. Sales personnel reported spending only 5.5 hours per week prospecting, which is significantly less than the 20 hours per week recommended by the Phoenix Coyotes in their sales training manual (Phoenix Coyotes, n.d.). It was surprising that more time per week was not allocated toward prospecting. It could be that customer relationship management database systems have become so efficient that a few clicks of a computer button can provide what many hours of prospecting could provide in the past.

With respect to the second research question, the results indicated that females spent more time on servicing accounts and organizational tasks than males. While this study could not determine whether females were better than males at servicing accounts, it did determine that they spend significantly more time on account servicing than males. This result falls in line with other research examining gender differences in salespeople outside the sport industry. Competence in sustaining relationships after the sale is an important component for sales professionals (Palmer \& Bejou, 1995). For example, Lane, Cravens, and Piercy (2000) found a great incidence of women exhibiting relational skills in sales compared to male counterparts. With the increasing importance of relationship marketing and relationship selling (Siguaw \& Honeycutt, 1995), the fact that women may be more capable of developing and maintaining sales relationships should be examined by organizations (Lane \& Crane, 2002). While sales personnel should not be tracked into 
specific types of positions based on gender, it is important for sales managers to ensure that employees with the right skill set are handling servicing efforts.

Time spent on sales tasks also varied by role within the organization. Account executives spent more time on prospecting and selling on the phone than directors, while directors spent more time on professional development and sales force management than account executives. This result is consistent with the finding of Pierce et al. (2012) where directors were more likely to engage in sales force management. The division of labor in a sales office is confirmed with the results of this research where entry-level personnel prospect for new customers and make sales calls, while directors engage in supervisory activities. In a similar result from this study, selling on phone was negatively correlated with years of experience while sales force management was positive correlated with years of experience. The transition between entry-level salesperson focused on selling on the phone to experienced salesperson selling a wide variety of products appears to occur at the end of the establishment career stage where salespeople have the opportunity to pursue a career track in sales force management. Because losing a productive sales person can result in a loss of sales productivity and replacement costs, sales managers must recognize when entry-level sales personnel have reached the end of the establishment career phase and are looking for career growth opportunities.

While Petersen et al. (2011) identified differences between major league and minor league sales position announcements, the results of this study indicated no significant differences between these two groups. This might be explained by the nature of what was being measured in the two studies. The current study measured hours per week, while the content analysis could only examine the presence of a statement in a job description, not a measure of how much time would be spent on the particular task.

How salespeople spend their time is fundamentally different depending on whether they are selling to groups and businesses or individual customers. Salespeople assigned to selling to groups and 
business (group tickets, premium seats, sponsorship) spent more time on prospecting, planning, presenting, preparing bids, and traveling. In contrast, salespeople assigned to selling season tickets (inside sales) spent more time selling on the phone. Inside sales positions are primarily focused on selling season ticket packages to individual customers over the phone. Leads are typically generated by management lists generated from the customer relationship database management system and are distributed to the inside sales staff. In contrast, selling to groups and businesses requires time spent in several areas. The use of various prospecting methods to identify new leads is important in order to keep new leads in the pipeline that cannot be culled from the existing database system. More time is needed for planning because of the uniqueness of each sales call along with the typically greater total value of the sale. Using a consultative sales approach, sales people will spend time qualifying the prospect and determining which group or sponsorship package would fulfill the clients" needs. More time is spent traveling and presenting since the presentation of a solution is unlikely to occur over the telephone. While the initial relationship may begin with a cold call on the phone, the development of the relationship occurs in person. Lastly, the preparation of bids is unique to selling to businesses, particularly when developing sponsorship proposals. Sport organizations should take into account that a one-size fits all approach to sales training may not yield the best results. Entry-level sales personnel focused on selling season tickets over the phone should have sales training efforts focused in specific areas such as needs analysis, overcoming objections, and closing; while more experienced sales personnel selling corporate packages may need focused training in prospecting, developing bids, and building longterm relationships.

From a management perspective, sales managers want to understand how time spent on various sales activities predicts job satisfaction, perceived ability to be successful in sales, sales performance, and persistence in sport sales. Similar to the previous research, however, there is little predictive ability in examining how much time salespeople spend on certain tasks. The number of hours 
worked per week was also not correlated with any of these dependent measures. From this result, it appears that working smart is more important than working hard. The only significant result was that time spent on sales force management and professional development were significant predictors of wanting to continue working sport sales. Those who have already achieved a position in sales force management are experienced and have passed the career exploration stage, and as in any industry those spending time to get better at their job (professional development) are more interested in staying in that field.

\section{Limitations}

It is important to note two limitations to the study. First, only $11.5 \%$ of the 4,611 survey recipients completed the survey. A higher response rate could have provided more robust results that could have improved the generalizability of the findings. Second, cost constraints prevented additional follow-up mailings to remind participants to complete the survey. Because only $10 \%$ of the sport salespeople possessed an email address available on the sport organization"s website, participants were contacted via a direct mailing from the US Postal Service. This method was significantly more costly than distributing the survey via email, but greatly expanded the potential subject pool.

\section{Future Research}

Future research in this area could utilize objective measures of sales performance such as actual sales data from the sport organization or the sales managers" perceptions of the salespersons" performance, instead of utilizing self-reported sales performance data. Future research could seek to more clearly define the four career stages and determine if sales production is impact by career stage and changes in how salespeople allocate their time. Finally, future research could assist in determining how salespeople can more efficiently spend their time on the types of sales activities examined in this study. 


\section{Conclusion}

As scholarly attention to the sales function within sport organizations continues to grow, it is important to examine and identify how salespeople spend their time. This study examined how sport salespeople spend their time on a variety of sales tasks and identified differences between types of sport sales jobs and salespeople. There is a clear demarcation of responsibilities between director and non-director positions, and between those with experience and those starting out in the career exploration stage. Significant differences were also identified between males and females that may have implications for sales managers attempting to identify those workers who can succeed in a relationship selling sales culture. However, there was little ability to predict sales performance and job satisfaction from how many hours per week salespeople spend on certain tasks.

\section{References}

Bae, S., \& Miller, J. (2011). A content analysis of sales and marketing job descriptions in the sport business industry: What should students be prepared for? International Journal of Sport Management, 12, 379-392.

Beck, J. A. (2006). The importance of sales managers" activities and time allocation toward job success in lodging properties. Journal of Human Resources in Hospitality \& Tourism, 5(2), $1-12$.

Beck, J. A., \& Knutson, B. J. (2006). An exploratory study of sales managers" activities in lodging properties. Journal of Hospitality \& Leisure Marketing, 15(1), 45-63.

Beetles, A., \& Crane, A. (2005). Mapping out the field of gender and buyer-seller relationships: Developing a new perspective. Journal of Marketing Management, 21, 231-250.

Bell R. L. (2011). Teaching present-day employees the value of scientific management. Supervision, 72(7), 5-8. 
Covell, D., Walker, S., Siciliano, J., \& Hess, P. (2007). Managing sport organizations: Responsibility for performance ( $2^{\text {nd }}$ ed.). Burlington, MA: Elsevier.

Cron, W. L. (1984). Industrial salesperson development: A career stages perspective. Journal of Marketing, 48, 41-52.

Groysberg, B. (2008). How star women build portable skills. Harvard Business Review, 86(2), 2-8.

Hair, J. F., Black, W. C., Babin, B. J., Anderson, R. E. (2010).

Multivariate data analysis (7th ed.). Upper Saddle River, NJ: Prentice Hall.

Heaston, R. (2005). The great gender debate. Giants, 1(5), 14. Howard, D., \& Crompton, J. (2004). Financing sport ( $2^{\text {nd }}$ ed.). Morgantown, WV: Fitness Information Technology.

Irwin, R. L., Sutton, W. A., \& McCarthy, L. (2008). Sport promotion and sales management. ( $2^{\text {nd }}$ ed.). Champaign, IL: Human Kinetics.

Kerber, K. W., \& Campbell, J. P. (1987). Correlates of objective performance among computer salespeople: Tenure, work activities, and turnover. Journal of Personal Selling \& Sales Management, 7, 39-50.

LaLonde, B. J., \& Morrison, E. J. (1967). Marketing management concepts yesterday and today. Journal of Marketing, 31(1), 913.

Lane, N., \& Crane, A. (2002). Revisiting gender role stereotyping in the sales profession. Journal of Business Ethics, 40(2), 121132.

Lane, N., Cravens, D., \& Piercey, N. (2000). Salesperson organizational citizenship behavior and sales unit effectiveness: Exploring the gender dimension. American Marketing Association Winter Conference. San Antonio, TX. Mason, D. (1999). What is the sports product and who buys it? The marketing of professional sports leagues. European Journal of Marketing, 33(3/4), 402-412.

McQuiston, D., \& Morris, K. (2009). Gender differences in communications: Implications for salespeople. Journal of Selling \& Major Account Management, 9, 54-64. 
Moncrief, W. C. (1986). Selling activity and sales position taxonomies for industrial salesforces. Journal of Marketing Research, 23, 261-270.

Moncreif, W. C., Marshall, G. W., \& Laask, F. G. (2006). A contemporary taxonomy of sales positions. Journal of Personal Selling \& Sales Management, 26(1), 55-65.

Palmer, A., \& Bejou, D. (1995). The effects of gender on the development of relationships between clients and financial advisors. International Journal of Bank Marketing, 13(3), 1827.

Petersen, J., Pierce, D., \& Judge, L. (2011). Major and minor league sales: A job postings content analysis. Paper presented at the Sport Marketing Association Conference. Houston, TX.

Phoenix Coyotes. (n.d.). Professional sports ticket sales training manual. Phoenix, AZ: Phoenix Coyotes.

Pierce, D., \& Petersen, J. (2010). Experiential learning in sport sales: Student perceptions of sport sales expectations, skills, and preparation. Sport Management Education Journal, 4(1), 4959.

Pierce, D., \& Petersen, J. (2011). Corporate sponsorship activation analysis in interscholastic athletics. Journal of Sponsorship, 4(3), 272-286.

Pierce, D., Petersen, J., Clavio, G., \& Meadows, B. (in press). Content analysis of sport ticket sales job announcements. Sport, Business, Management: An International Journal.

Pierce, D., Petersen, J., \& Meadows, B. (2011). Authentic assessment of experiential learning in sport sales. Sport Marketing Quarterly, 20(2), 75-83.

Siguaw, J., \& Honeycutt, E. (1995). An examination of gender differences in selling behaviors and job attitudes. Industrial Marketing Management, 24, 45-52.

Smith, G. J., \& Roy, D. P. (2011). A framework for developing customer orientation in ticket sales organizations. Sport Marketing Quarterly, 20(2), 93-102. 
Weeks, W. A., \& Kahle, L. R. (1990). Salespeople"s time use and performance. Journal of Personal Selling \& Sales Management, 10, 29-37.

Weitz, B., Castleberry, S., \& Tanner, J. (2009). Selling: Building partnerships, $7^{\text {th }} e d$. New York: McGraw-Hill Irwin. 